[Radiocarbon, Vol. 21, No. 2, 1979, P. 165-170]

\title{
GLIWICE RADIOCARBON DATES V
}

ANNA PAZDUR, MIECZYSLAW F PAZDUR, and ANDRZEJ ZASTAWNY

Institute of Physics, Silesian Technical University, PL-44-100

Gliwice, ul Krzywoustego 2, Poland

Most of the dates reported in this list were obtained between November 1975 and December 1976. All samples were subjected to standard de Vries pretreatment. Age calculations are based on a contemporary value equal to 0.95 of the activity of NBS oxalic acid standard and on the Libby value for the half-life of radiocarbon. Results are reported as conventional radiocarbon dates in years before AD 1950. All measurements were made with our L1 counter (Mościcki \& Zastawny, 1976). Counting rates of all samples were normalized to the standard value of $\mathrm{CO}_{2}$ pressure and corrected for the counting efficiency (Pazdur et al, 1978). Errors quoted $( \pm 1 \sigma)$ include estimated overall standard deviations of count rates for the unknown sample, contemporary standard and background (Pazdur, \& Walanus, in press). No corrections for ${ }^{13} \mathrm{C} /{ }^{12} \mathrm{C}$ ratio were made for measurements reported in this list. The value of $\delta^{13} \mathrm{C}$ for our NBS oxalic acid standard is equal to $-19.41 \%$ relative to the PDB standard. The descriptions of the samples are based on information provided by the submitters.

\section{SAMPLE DESCRIPTIONS}

\section{Leba Bar series}

GEOLOGIC SAMPLES

Samples from dunes on Leba Bar at Baltic coast dated for geomorphol and stratigraphic investigations of Leba Bar coastal dunes (Borówka, 1975; Tobolski, 1975). Subm by Stefan Kozarski, Inst Geog, A Mickiewicz Univ, Poznań.

Gd-421. Czolpino 1/73-KB

$3340 \pm 130$

Charcoal from depth 3.1 to $3.2 \mathrm{~m}$. Both Cołpino samples are from fossil soil levels in dune, ca $1.7 \mathrm{~km} \mathrm{NE}$ of Czołpino (54 $43^{\circ} \mathrm{N}, 17^{\circ} 15^{\prime} \mathrm{E}$ ). Coll Sept 1973 by Krzysztof Borówka.

Gd-422. Czolpino 2/73-KB

$\mathbf{3 9 0} \pm \mathbf{1 2 0}$

Fragments of pine wood partially charred from depth ca $1 \mathrm{~m}$. Comment: previous dates from this region, assoc with same problem, see Gd-137: $850 \pm 100$ and Gd-154: $860 \pm 100$ (R, 1976, v 18, p 51).

Gd-418. Leba-Neptun 1/34-38cm

$1435 \pm 140$

Sandy well-decomposed peat from depth 34 to $38 \mathrm{~cm}$. All 3 LebaNeptun samples are from different depths of organic layer ranging from $+50 \mathrm{~cm}$ to $-60 \mathrm{~cm}$, on beach overlain by coastal dune, $200 \mathrm{~m} \mathrm{E}$ of LebaNeptun $\left(54^{\circ} 46^{\prime} 10^{\prime \prime} \mathrm{N}, 17^{\circ} 34^{\prime} 05^{\prime \prime} \mathrm{E}\right)$. Coll Nov 1975 by Kazimierz Tobolski.

Gd-416. Leba-Neptun 2/79-84cm

$2450 \pm 140$

Wood peat mixed with sand, depth 79 to $84 \mathrm{~cm}$. 
Gd-415. Leba-Neptun $3 / 105-109 \mathrm{~cm}$

$4610 \pm 250$

Algae gyttja from depth 105 to $109 \mathrm{~cm}$. Comment (KT): penetration of younger rootlets is possible. According to pollen analysis 1st sample is from younger part of Sub-Boreal period, 2nd-Sub-Boreal period, 3rdtransition between Atlantic and Sub-Boreal.

Gd-419. Steknica $7 /$ BN/75

$1340 \pm 110$

Charcoal from fossil soil level $1.2 \mathrm{~m}$ below dune surface $1 \mathrm{~km} \mathrm{~N}$ of Steknica v near Leba $\left(54^{\circ} 44^{\prime} \mathrm{N}, 17^{\circ} 35^{\prime} \mathrm{E}\right)$. Coll Nov 1975 by Bolesław Nowaczyk.

\section{Great Poland Lowland Dunes series}

Samples from organic levels dated for geomorphic and stratigraphic investigation of dune formation processes in Great Poland Lowland. Coll by Bolesław Nowaczyk and subm 1975 by Stefan Kozarski.

\section{Gd-357. Budzyń 3/BN/75}

$11,400 \pm 320$

Charcoal from fossil soil level at depth ca $180 \mathrm{~cm}$ in parabolic dune $4.5 \mathrm{~km} \mathrm{~W}$ of Budzyń v, Gniezno Uplands (52 $\left.53^{\prime} 30^{\prime \prime} \mathrm{N}, 16^{\circ} 56^{\prime} 50^{\prime \prime} \mathrm{E}\right)$ Coll Oct 1973.

Gd-371. Budzyń 4/BN/75

Charcoal from younger organic level at same place, depth 80 to $90 \mathrm{~cm}$, coll Feb 1975.

\section{Gd-378. Pomorsko 8/BN/75}

$11,380 \pm 275$

Wood from $\log$ found below series of aeolian sediments on lime gyttja filling up glacial trough in Warsaw-Berlin Ice-Marginal Valley at

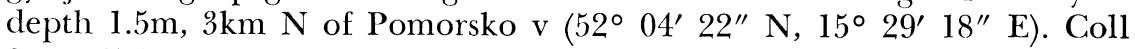
Sept 1974.

Gd-366. Szabliska 6/BN/75

$$
460 \pm 130
$$

Charcoal from humus level appearing as thin insertion separating outwash plain sands and dune sands in deflation surface $0.7 \mathrm{~km} \mathrm{E}$ of Szabliska v, Lubusko Uplands (52 $\left.05^{\prime} 06^{\prime \prime} \mathrm{N}, 15^{\circ} 31^{\prime} 50^{\prime \prime} \mathrm{E}\right)$. Coll March 1975, dated to establish end of erosional formation of denudational valley.

\section{Gd-379. Osno Lake 5/BN/75}

$12,330 \pm 290$

Moss peat from base of glacial trough, thin layer at depth 5.15 to $5.19 \mathrm{~m}$, ca $10 \mathrm{~km}$ SE of Kargowa v $\left(52^{\circ} 01^{\prime} 47^{\prime \prime} \mathrm{N}, 15^{\circ} 59^{\prime} 20^{\prime \prime} \mathrm{E}\right)$. Coll March 1975 by Bolesław Nowaczyk, subm by Stefan Kozarski. Comment (SK): moss peat layer appears below lime gyttja basal part of which was dated to birch phase of Allerod. Sample dated to establish age of melting of dead ice blocks buried in glacial trough and to determine age of aeolian sediments filling in base of trough.

\section{Jaszkowo series}

Samples of sandy mud with rich admixture of plant detritus, continuous layer between calcareous gyttja in fossil meander channel on 
Warta R floodplain, $3.5 \mathrm{~km} \mathrm{~N}$ of Jaszkowo v $\left(52^{\circ} 10^{\prime} \mathrm{N}, 16^{\circ} 57^{\prime} \mathrm{E}\right)$. Coll June 1975 by Kazimierz Tobolski and Bolesław Nowaczyk; subm by Stefan Kozarski. Samples dated to investigate floodplain deposits stratigraphy and changes of Warta $\mathrm{R}$ during Late Glacial and Holocene (Kozarski \& Rotnicki, 1977; Kozarski, 1974).

Gd-387. Jaszkowo Ja/74/AI/374-380

$$
11,430 \pm 630
$$

From depth 374 to $380 \mathrm{~cm}$.

Gd-381. Jaszkowo Ja/74/AI/360-366

From depth 360 to $366 \mathrm{~cm}$.

Gd-380. Jaszkowo Ja/74/AI/349-355

From depth 349 to $355 \mathrm{~cm}$.

General Comment (KT): introductory pollen analysis showed Younger Dryas period. Sample from upper gyttja layer previously dated, Gd-293: $9650 \pm 240$ (Mościcki et al, 1978).

\section{Bobr R series}

Dates measured for geomorphol studies of floodplain development during Late Würm and Holocene. Samples coll Nov 1975 by Wacław Florek, subm by Stefan Kozarski.

Gd-408. Wysoka Wy/75/1

$3520 \pm 180$

Decomposed leaf and wood peat deposit in situ as contiñuous peat layer in middle part of filling series in an oxbow lake, base of Bóbr valley, depth 1.60 to $1.70 \mathrm{~m}, 2 \mathrm{~km} \mathrm{NW}$ of Wysoka v $\left(51^{\circ} 52^{\prime} 30^{\prime \prime} \mathrm{N}, 15^{\circ} 10^{\prime} \mathrm{E}\right)$.

\section{Gd-407. Gorzupia Dolna Go/75/1}

$4610 \pm 200$

Oak trunk found in situ in old meandering channel at base of Bóbr $\mathrm{R}$ valley, $880 \mathrm{~m} \mathrm{~N}$ of Gorzupia Dolna $\left(51^{\circ} 44^{\prime} 30^{\prime \prime} \mathrm{N}, 15^{\circ} 15^{\prime} \mathrm{E}\right)$. Trunks occur in gravelly channel deposits covered by sands and muds. From depth $3.75 \mathrm{~m}$.

Gd-406. Gorzupia Dolna Go/75/2

$4590 \pm 200$

Same, from depth $3.80 \mathrm{~m}$.

Gd-396. Gorzupia Dolna Go/75/3

$5180 \pm 180$

Same, from depth $3 \mathrm{~m}$.

Gd-405. Gorzupia Dolna Go/75/4

$\mathbf{5 2 3 0} \pm 210$

Same, from depth $3 \mathrm{~m}$.

Gd-440. Zamrzenica 1

$12,020 \pm 350$

Clayey gyttja layer at depth 10.40 to $10.50 \mathrm{~m}$ in subglacial channel crossing outwash plain and Brda $\mathrm{R}$ terraces in Zamrzenica, $3 \mathrm{~km} \mathrm{E}$ of

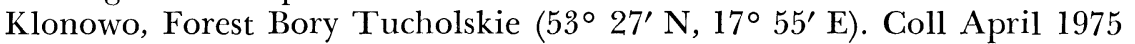
and subm by Rajmund Galon, Inst Geog, M Kopernik Univ, Torun (Galon, 1965; Kępczyński, 1958). 


\section{Mietlica series}

Samples from organic layers in vanished bay of Gopło Lake, $380 \mathrm{~m} \mathrm{E}$ of Mietlica v, Kuyavian Lake Dist (52 $32^{\prime} 26^{\prime \prime} \mathrm{N}, 18^{\circ} 23^{\prime} 26^{\prime \prime} \mathrm{E}$ ). Coll Sept 1975 and subm by Władysław Niewiarowski, Inst Geog, M Kopernik Univ, Torun.

\section{Gd-395. Mietlica 1}

$8175 \pm 250$

Peat from depth 1.9 to $2 \mathrm{~m}$.

\section{Gd-403. Mietlica 2}

Detrital gyttja from depth $0.85 \mathrm{~m}$.

\section{Gd-404. Mietlica 3}

$760 \pm 160$

Mud mixed with sand from depth $0.1 \mathrm{~m}$.

General Comment (WN): other dates from Pakoskie Lake in vicinity of Mietlica site (R, 1973, v 15, p 503-504).

\section{Swietokrzyskie Mt Rivers series}

Subfossil oak from lowest level of flood terraces in Swiętokrzyskie Mts, dated at Lower Holocene (Lindner, 1971; Hakenberg \& Lindner, 1973; Lindner, 1977). Coll Sept 1974 by Leszek Lindner, subm by S Z Rózycki, Inst Geol, Warsaw Univ, Warsaw.

\section{Gd-360. Tama n/Czarna}

$1300 \pm 130$

Oak wood, fragments of tree-trunk lying $1.9 \mathrm{~m}$ below surface in deposits of flood terrace of Czarna Sulejowska R, $400 \mathrm{~m} \mathrm{~N}$ of Tama v $\left(51^{\circ}\right.$ $\left.11^{\prime} \mathrm{N}, 20^{\circ} 11^{\prime} \mathrm{E}\right)$.

\section{Gd-370. Wolica $\mathrm{n} /$ Nida}

$1190 \pm 120$

Oak wood, fragments of tree trunk found $1.8 \mathrm{~m}$ below surface in deposits of flood terrace of Cizarna Nida R, $450 \mathrm{~m} \mathrm{NW}$ of Wolica v $\left(50^{\circ} 46^{\prime}\right.$ $\left.\mathrm{N}, 20^{\circ} 29^{\prime} \mathrm{E}\right)$.

General Comment (I.L): samples of black oak from Machów region were dated at Groningen (Mycielska-Dowgiałło, 1972); see also Mościcki (1953).

\section{Niechorze sericg}

Peat from organic deposits of 2 lake basins displayed in seashore cliffs exposed near Niechorze v, Western Pomerania. Samples with code Eo are from E lake ca $1.7 \mathrm{~km} \mathrm{~W}$ of Niechorze $\left(54^{\circ} 05^{\prime} 35^{\prime \prime} \mathrm{N}, 15^{\circ} 19^{\prime} \mathrm{E}\right)$; those with code $W o$ are from $W$ lake, ca $2.3 \mathrm{~km} \mathrm{~W}$ of Niechorze $\left(54^{\circ} 05^{\prime}\right.$ $30^{\prime \prime} \mathrm{N}, 15^{\circ} 24^{\prime} \mathrm{E}$ ). Coll Aug 1974 by Ewa Brykczyńska, subm by Krystyna Kopczyńska-Lamparska, Inst Geol, Warsaw Univ, Warsaw.

Gd-376. Niechorze Eol

$750 \pm 120$

Peat mixed with sand from thin fossil soil layer at depth $1.3 \mathrm{~m}$.

Gd-359. Niechorze Eo2

$2760 \pm 130$

From top of peat bed in fossil lake basin at depth $2.8 \mathrm{~m}$. 
Gd-369. Niechorze Eo3

$6310 \pm 170$

From bottom of peat bed in fossil lake basin at depth $3.3 \mathrm{~m}$.

Gd-373. Niechorze Eo4

$12,920 \pm 330$

From thin peat layer at depth $5.3 \mathrm{~m}$, overlain by lake slimes.

Gd-372. Niechorze Wo2

$2880 \pm 130$

From top of peat bed in fossil lake basin, depth $2.2 \mathrm{~m}$.

Gd-367. Niechorze Wo3

$10,140 \pm 220$

From base of peat bed, depth $3.5 \mathrm{~m}$.

General Comment (KKL): pollen and diatom analyses and results of radiocarbon dating enabled identification of Oldest Dryas for 1st time in NW Poland (Kopczyńska-Lamparska, 1976). Youngest date falls within interval of formation of so-called "yellow dunes" in coastal zone (Prusinkiewicz \& Noryśkiewicz, 1966).

\section{Janoszyce series}

Peat from different beds separated and underlain by lacustrine chalk in fossil lake basin of Janoszyce subglacial channel $\left(52^{\circ} 40^{\prime} 30^{\prime \prime} \mathrm{N}, 19^{\circ}\right.$ 33' E), Dobrzyń Lakelalnd, 16km NW of Płock city. Coll Sept 1974 and subm by Zbigniew Lamparski, Inst Geol, Warsaw Univ, Warsaw. Samples dated to establish origin and development of Janoszyce channel in relation to Wierzbica subglacial channel and Zuchowo basin (Lamparski, 1976; Skompski \& Słowański, 1964; Kozłowska, 1972).

Gd-374. Janoszyce Js1

$9910 \pm 290$

From upper bed, depth $2.2 \mathrm{~m}$.

\section{Gd-375. Janoszyce Js2}

$11,130 \pm 290$

From lower bed, depth $4.3 \mathrm{~m}$.

General Comment (ZL): 2 samples from neighboring sec were dated earlier; they were believed to be from different beds but results GrN-6771: $11,300 \pm 95$ and GrN-6772: 11,800 \pm 100 indicate Allerod age for both samples.

\section{REFERENCES}

Borówka, Krzysztof, 1975, Problem of the morphology of fossil dune forms on the Leba Bar: Quaest Geog, v 2, p 39-51.

Galon, Rajmund, 1965, Some new problems concerning subglacial channels: Geog Polon, no. 6.

Hakansson, Sören, 1973, University of Lund radiocarbon dates VI: Radiocarbon, v 15 , p 493-513.

Hakenberg, M and Lindner, Leszek, 1973, Holoceński rozwój doliny środkowej Nidy (with English summary): $\Lambda$ cta Geol Pol, v 23, p 435-445.

Kepczyński, K, 1958, Roślinność i historia torfowiska Siwe Bagno w Borach Tucholskich: Univ M Kopernika, Zesz Nauk, ser Biol, no. 2.

Kopczyńska-Lamparska, Krystyna, 1976, Radiocarbon datings of the Late Glacial and Holocene deposits of Western Pomerania: Acta Geol Pol, v 26, p 413-418.

Kozarski, Stefan, 1974, Stanowisko Jaszkowo kolo Sremu. Migracja koryta Warty na poludnie od Poznania w póznym glacjale i holocenie - generacja meandrów (with English summary): Rozwój den dolinnych ...., Krajowe symposium, WroclawPoznań, 1974, excursion guidebook, p 49-55. 
Kozarski, Stefan and Rotnicki, Karol, 1977, Valley floors and changes of river channel patterns in the North Polish Plain during the Late-Würm and Holocene: Quaest Geog, v 4, p 51-93.

Kozlowska, M, 1972, Origin of subglacial furrow near Sierpc, Central Poland: Acta Geol Pol, v 22, p 159-168.

Lamparski, Zbigniew, 1976, New radiocarbon datings of the Late Glacial and Holocene organic deposits of the Janoszyce furrow, Dobrzyń Lakeland: Acta Geol Pol, v 26, p $419-428$

Lindner, Leszek, 1971, Stratygrafia plejstocenu i paleogeografia pólnocno-zachodniego obrzezenia Gór Swiętokrzyskich: Studia Geol Pol, v 35, p 1-113.

1977, Wiek terasów zalewowych rzek świẹtokrzyskich w świetle datowania "poziomu czarnych dębów" metoda ${ }^{14} \mathrm{C}$ (with English summary): Kwart Geol, v 21, p 325-334.

Mościcki, Wlodzimierz, 1953, Pierwsze wyniki datowania wieku drewna kopalnego w Polsce metoda radiowęgla (with English summary): Acta Geol Pol, v 3, p 187-189.

Mościcki, Wlodzimierz and Zastawny, Andrzej, 1976, Gliwice (Gdańsk) radiocarbon dates III: Radiocarbon, v 18, p 50-59.

Mościcki, Wlodzimierz, Pazdur, Anna, Pazdur, Mieczyslaw F, and Zastawny, Andrzej, 1978, Gliwice radiocarbon dates IV: Radiocarbon, v 20, p 405-415.

Mycielska-Dowgiallo, Elzbieta, 1972, Rozwój doliny środkowej Wisly w holocenie w świetle badań z okolic Tarnobrzega: Przegl geog, v 44, p 73-83.

Pazdur, Mieczyslaw $\mathbf{F}$ and Walanus, Adam, 1978, Statistical processing of data and age calculations in Gliwice Radiocarbon Laboratory: Muz Arch i Etnogr w Lodzi, Prace i Materialy, $v 26$, in press.

Pazdur, Mieczyslaw F, Walanus, Adam, and Móscicki, Wlodzimierz, 1978, A method of continuous examination of the counting efficiency during natural radiocarbon measurements with a $\mathrm{CO}_{2}$ filled proportional counter: Nuclear Instruments Methods, v 151, p 541-547.

Prusinkiewicz, Zbigniew and Noryśkiewicz, Bozena, 1966, Problem of age of podzols on brown dunes of bay bars of river Swina in the light of a palynological analysis and dating by radiocarbon ${ }^{14} \mathrm{C}$ : Univ M Kopernika, Zesz Nauk, ser geog, v 5, p 75-88.

Skompski, S and Slowański, w, 1964, La valée polygénétique de Wierzbica prés de Plock: Acta Geol Pol, v 14, p 437-457.

Tobolski, Kazimierz, 1975, Studium palinologiczne gleb kopalnych Mierzei Lebskiej w Slowińskim Parku Narodowym (with English summary): Pozn Tow Przyj Nauk, Kom Biol, Prace, v 41, p 1-76. 